STUDIA POLONIJNE

T. 41. LUBLIN 2020

DOI: http://doi.org/10.18290/sp2041-6

JÓZEF WOŁCZAŃSKI

\title{
DZIALALNOŚĆ DYDAKTYCZNO-NAUKOWA KS. JANA ŚLÓSARZA NA WYDZIALE TEOLOGICZNYM UNIWERSYTETU LWOWSKIEGO W LATACH 1886-1903
}

Kandydaci na wykładowców dyscyplin filozoficzno-teologicznych w drugiej połowie XIX-wiecznej Galicji na fakultetach teologicznych Uniwersytetu Jagiellońskiego w Krakowie czy Uniwersytetu im. cesarza Franciszka I we Lwowie, a także w diecezjalnych Instytutach Teologicznych Przemyśla i Tarnowa, zasadniczo musieli legitymować się dyplomami doktorskimi. Stopnie naukowe doktora teologii, filozofii lub prawa kanonicznego duchowni uzyskiwali wówczas najczęściej na Zachodzie Europy: w Rzymie, Wiedniu, Innsbrucku, Fryburgu Szwajcarskim oraz kilku niemieckich uniwersytetach, rzadziej natomiast w Krakowie i Lwowie ${ }^{1}$.

Formuła wykształcenia poza Galicją na poziomie studiów doktoranckich dotyczyła też duchownego archidiecezji lwowskiej obrządku łacińskiego ks. Jana Ślósarza (1850-1917). Po ukończeniu czteroletnich studiów na Wydziale Teologicznym Uniwersytetu Lwowskiego (1875-1879), a zarazem odbyciu formacji ascetyczno-moralnej w Seminarium Duchownym we Lwowie i uzyskaniu w roku 1879 święceń kapłańskich, początkowo został skierowany na posadę wikariusza w parafii Bełz. Spędził tam zaledwie jeden rok, po czym ówczesny metropolita lwowski, abp Seweryn Morawski wysłał go na dalsze studia do Wiednia. Jako stypendysta Wyższego

Ks. prof. dr hab. Józef WolCZAŃSKi - Instytut Historii i Dziedzictwa Kulturowego na Uniwersytecie Papieskim Jana Pawła II w Krakowie; e-mail: jwolczan@wp.pl. ORCID: https://orcid. org/0000-0001-6210-1411.

1 Wydzial Teologiczny Uniwersytetu Jana Kazimierza we Lwowie 1918-1933, red. zbior., Lwów 1934; M. Kanior, Wydziat Teologiczny w dziejach Uniwersytetu Krakowskiego (1780-1880), Kraków 1998, passim; J. WoŁCZAŃsKi, Wydziat Teologiczny Uniwersytetu Jana Kazimierza we Lwowie 1918-1939, Kraków 2002, passim; TENŻE, Wydział Teologiczny, w: Academia militans. Uniwersytet Jana Kazimierza we Lwowie, red. A. Redzik, Kraków 2017, s. 291-383; W. KocHowski, Historia Seminarium Duchownego diecezji przemyskiej obrządku łacińskiego 1687-1895, oprac. J. Wołczański, Lwów-Kraków 2011, passim; S. PIECH, Wydział Teologiczny Uniwersytetu Jagiellońskiego w latach 1880-1939, Kraków 1995, passim; TENŻE, Wychować dla Kościoła i państwa. Formacja elity duchowieństwa galicyjskiego w Wiedniu 1775-1918, Kraków 2012, passim. 
Instytutu Naukowego dla Księży Diecezjalnych w byłym klasztorze św. Augustyna zwanym Augustineum lub Frintaneum ${ }^{2}$, studiował na Wydziale Teologicznym Uniwersytetu Wiedeńskiego od 30 IX 1880 do 29 IX 1885 r. $^{3}$ Podobnie jak na etapie lwowskim, tak i tym razem przedmiotem studiów była teologia bez ściśle określonej specjalizacji. Zachowane źródła wskazują wszakże niektóre dyscypliny, którym ks. Ślósarz zdawał się poświęcać więcej uwagi. I tak w roku akad. 1880/81 uczęszczał na wykłady o. prof. Wilhelma Neumanna OCist z biblistyki, a dokładniej rzecz ujmując - z egzegezy wyższej Księgi Koheleta, oraz ks. prof. Karla Wernera z egzegezy wyższej 2 Listu do Koryntian. Poza tym uczestniczył w lektoratach z języków chaldejskiego i syryjskiego. Kilka lat później, w roku akad. 1883/84 studiował pod kierunkiem ks. prof. Franza Laurina prawo kanoniczne $e^{4}$.

Długie, bo pięcioletnie studia zostały uwieńczone zdobyciem stopnia naukowego doktora teologii na podstawie zdanych pomyślnie rygorozów i rozprawy pt.: „Lis de investitura inter Pontifices Romanos et imperatores Romano-Germanicos saeculi 11 et 12 agitata", liczącej w rękopisie 120 stronic $^{5}$. Promocja doktorska miała miejsce 21 X 1885 r. w Wiedniu 6 .

Po powrocie do Lwowa ks. dr Ślósarz objął obowiązki wikariusza w parafii pw. Matki Bożej Śnieżnej (1885-1888) i katechety IV Gimnazjum (1886-1890)º Obie te posady nie zaspokajały wszakże ambicji 35-letniego wówczas duchownego, marzącego zapewne - czego dowodziły podjęte niebawem przezeń starania - o karierze naukowej. Zaledwie po upływie roku od promocji doktorskiej, wniósł on 3 XI 1886 r. podanie do Rady Wydziału Teologicznego Uniwersytetu Lwowskiego o zatrudnienie go tamże na stanowisku adiunkta. Na poparcie swych starań przytoczył ważkie argumenty: ukończenie w 1879 r. z wynikiem celującym lwowskiej Wszechnicy oraz uzyskanie doktoratu na Uniwersytecie Wiedeńskim. Dodawał nadto passus natury „ad captandam benevolentiam”: „Podpisany pragnie wspomniany materiał naukowy zużytkować dla tutejszego wydziału teologicznego, jako adiunkt według potrzeby; największe zaś dobrodziejstwo łaskawego przychylenia się do jego proś-

${ }^{2}$ K.H. FrankL, Das Höhere Priesterbildungsinstitut zu St. Augustin in Wien (,,Frintaneum”), w: Das ,Frintaneum in Wien” und seine Mitglieder aus den Kirchenprovinzen Wien, Salzburg und Görz (1816-1918). Ein biographisches Lexikon, hgg. K.H. Frankl, P.G. Tropper, Ljubljana-Wien 2006, s. $21-38$.

3 S.L. Piech, Wychować dla Kościoła, s. 190.

${ }^{4}$ Tamże, s. 162.

${ }^{5}$ Tamże, s. 251.

6 Tamże; J. Wolczański, Ślósarz Jan, w: Polski Stownik Biograficzny, t. 51, red. zbior., Warszawa-Kraków 2016, s. 42-43.

${ }^{7}$ Derżawnyj Archiw Lwiwśkoji Obłasti u Lwowi [dalej: DALO], f. 26, op. 13, nr 186, Teczka personalna ks. Jana Ślósarza, J. Ślósarz, [Curriculum vitae], Lwów 27 X 1901 r. 
by upatruje w tym, iż miałby nieocenioną sposobność korzystania z kierownictwa i wskazówek Przewielebnego Kolegium na polu dalszej ściśle naukowej pracy, której z całą sumiennością swą dalszą działalność poświęcić pragnie"8.

Okoliczności wyraźnie sprzyjały ewentualnym kandydatom, bowiem wygasł wówczas przewidziany prawem dwuletni angaż na stanowisku adiunkta ks. dr. Alojzego Jougana (1855-1942), katechety gimnazjalnego i prefekta alumnów Seminarium Duchownego we Lwowie. Ale ks. Ślósarz nie był bynajmniej jedynym kandydatem aspirującym na wakujący etat. W tym samym czasie analogiczne starania podjął inny absolwent Uniwersytetu Wiedeńskiego, a zarazem rówieśnik w doktorskiej promocji ks. Ślósarza, ks. dr Błażej Jaszowski (1856-1921)9. Podania obu wspomnianych kandydatów rozpatrywano podczas posiedzenia Rady Wydziału Teologicznego dnia 23 XI 1886 r. W drodze głosowania, większością głosów wakujący etat przyznano na okres dwóch lat ks. dr. Slósarzowi. Wprawdzie obaj kandydaci mieli równe szanse, ale prawdopodobnie zadecydowała przesłanka wieku: zwycięzca legitymował się starszą o sześć lat metryką urodzenia ${ }^{10}$.

Po zakończonej elekcji dziekan fakultetu, ks. prof. Marceli Paliwoda skierował 23 XI 1886 r. pismo do Konsystorza Metropolitalnego ob. łac. we Lwowie z informacją o wynikach głosowania, a zarazem z prośbą o veniam docendi dla nowego adiunkta. Przy okazji zdefiniowano zakres jego obowiązków: „[...] zastępowanie XX. profesorów teologicznych w razie ich przeszkody" ${ }^{\prime 1}$. Jak z tego wynika, nowe obowiązki nie miały ściśle określonego charakteru, ale były dostosowywane ad hoc do bieżących potrzeb fakultetu. Jednocześnie dziekan wystosował pismo z analogiczną petycją do Konsystorza Metropolitalnego obrządku greckokatolickiego we Lwowie, ponieważ na wykłady uniwersyteckie uczęszczali także alumni uniccy. Pozytywna decyzja ze strony abp. Seweryna Morawskiego nadeszła 3 I 1887 r., zaś metropolita unicki Sylwester Sembratowicz swoją aprobatę podpisał 28 stycznia tego samego roku ${ }^{12}$.

Kontynuując finalizację formalności, dziekan fakultetu ks. prof. Paliwoda wystosował pismo 23 XI 1886 r. do Namiestnictwa we Lwowie z prośbą o wypła-

${ }^{8}$ DALO, f. 26, op. 13, nr 186, Teczka personalna ks. Jana Ślósarza, J. Ślósarz, [Podanie do Rady Wydziału Teologicznego Uniwersytetu Lwowskiego], Lwów 3 XI 1886 r.

9 DALO, f. 26, op. 13, nr 186, Teczka personalna ks. Jana Ślósarza, [M. Paliwoda, Nota dziekana Wydziału Teologicznego Uniwersytetu Lwowskiego w sprawie obsady stanowiska adiunkta], Lwów 6 XI 1886 r.

10 J. WolcZaŃsKi, Jaszowski Błażej, w: Encyklopedia Katolicka, t. VII, Lublin 1997, kol. 1115.

${ }^{11}$ DALO, f. 26, op. 13, nr 186, Teczka personalna ks. Jana Ślósarza, [M. Paliwoda, Kopia pisma do Konsystorza Metropolitalnego ob. łac.], Lwów 23 XI 1886 r.

${ }^{12}$ DALO, f. 26, op. 13, nr 186, Teczka personalna ks. Jana Ślósarza, S. Morawski, Odezwa, Lwów 3 I 1887 r.; DALO, f. 26, op. 13, nr 186, Teczka personalna ks. Jana Ślósarza, S. Sembratowicz, Nota, Leopoli 28 I $1887 \mathrm{r}$. 
canie nowemu adiunktowi ks. dr. Ślósarzowi od 24 XI 1886 r. do 30 IX 1888 r. kwoty 105 złr rocznie w miesięcznych ratach ${ }^{13}$. Stosowne rozporządzenie w tej kwestii Namiestnictwo wydało 29 XII 1886 r. Głównej Kasie Krajowej we Lwowie $^{14}$. O decyzjach tych poinformował samego zainteresowanego dziekan fakultetu, ks. prof. Paliwoda, odrębnym pismem z 24 I $1887 \mathrm{rr}^{15}$

Po upływie dwuletniej kadencji, ks. Ślósarz wniósł 5 X 1888 r. do Rady Wydziału Teologicznego Uniwersytetu Lwowskiego pismo z prośbą o prolongatę adiunktury na kolejne dwa lata ${ }^{16}$. Petycja ta została pozytywnie rozpatrzona podczas posiedzenia grona profesorów 24 XI 1888 r., jednomyślnie akceptujących starania petenta ${ }^{17}$. Tak jak poprzednim razem, tak i teraz zwrócono się do Namiestnictwa o wypłacanie poborów adiunktowi w takiej samej wysokości 105 złr rocznie przez kolejne dwulecie ${ }^{18}$. Urzędnicy Namiestnictwa ponownie nadali bieg tej sprawie, zlecając jej realizację Głównej Kasie Krajowej we Lwowie ${ }^{19}$. Reasumując należy dodać, iż status adiunkta Wydziału Teologicznego posiadał ks. Ślósarz od roku akad. 1886/87 do roku akad. 1890/91 włącznie ${ }^{20}$.

O ile w pierwszej kadencji ks. Ślósarz nie pełnił żadnych praktycznych funkcji na Wydziale Teologicznym, o tyle w drugiej pojawiły się dlań nowe wyzwania. Tak więc zimą 1888 r., po Bożym Narodzeniu, otrzymał on służbowe polecenie od dziekana fakultetu, ks. prof. Jana Bartoszewskiego, objęcia zastępstwa wykładów z Nowego Testamentu w miejsce chorego ks. prof. Józefa Watzki (1831-1908)21.

${ }^{13}$ DALO, f. 26, op. 13, nr 186, Teczka personalna ks. Jana Ślósarza, [M. Paliwoda, Kopia pisma do Namiestnictwa we Lwowie], Lwów 23 XI $1886 \mathrm{r}$.

${ }^{14}$ DALO, f. 26, op. 13, nr 186, Teczka personalna ks. Jana Ślósarza, [Kopia pisma Namiestnictwa do Głównej Kasy Krajowej we Lwowie], Lwów 29 XII 1886 r.

${ }^{15}$ DALO, f. 26, op. 13, nr 186, Teczka personalna ks. Jana Ślósarza, M. Paliwoda, [Kopia pisma dziekana Wydziału Teologicznego Uniwersytetu Lwowskiego do ks. J. Ślósarza], Lwów 24 I 1887 r.

16 DALO, f. 26, op. 13, nr 186, Teczka personalna ks. Jana Ślósarza, J. Bartoszewski, [Nota w sprawie petycji ks. J. Ślósarza o przedłużenie kadencji adiunkta], Lwów 5 X 1888 r.

${ }^{17}$ DALO, f. 26, op. 13, nr 186, Teczka personalna ks. Jana Ślósarza, J. Bartoszewski, [Kopia pisma dziekana Wydziału Teologicznego Uniwersytetu Lwowskiego do ks. J. Ślósarza], Lwów 26 XI 1888 r.

${ }^{18}$ DALO, f. 26, op. 13, nr 186, Teczka personalna ks. Jana Ślósarza, J. Bartoszewski, [Kopia pisma dziekana Wydziału Teologicznego Uniwersytetu Lwowskiego do Namiestnictwa we Lwowie], Lwów 26 XI 1888 r.

19 DALO, f. 26, op. 13, nr 186, Teczka personalna ks. Jana Ślósarza, [Kopia pisma Namiestnictwa do Głównej Kasy Krajowej we Lwowie], Lwów 30 XI 1888 r.

${ }^{20}$ DALO, f. 26, op. 13, nr 186, J. Ślósarz, Teczka personalna ks. Jana Ślósarza, [Curriculum vitae], Lwów 27 X 1901 r.; C.K. Uniwersytet imienia cesarza Franciszka I we Lwowie. Sktad Uniwersytetu i program wykładów 1886/87-1890/91, Lwów 1886-1891, passim.

${ }^{21}$ Wydziat Teologiczny Uniwersytetu Jana Kazimierza we Lwowie 1918-1933, s. 23; J. OwSINŚKYJ, Watcka (Watzka) Józef, w: Lwiwśkyj nacionalnyj uniwersytet imeni Iwana Franka. Encyklopedia, t. I, red. zbior., Lwiw 2011, s. 271. 
Zarówno czas, jak i zakres zastępstwa miał ustalić osobiście z niedysponowanym uczonym $^{22}$. Nieznany jest wszakże rezultat tegoż angażu, bowiem został on podjęty ad hoc, czego oczywiście nie wykazały drukowane katalogi wykładów uniwersyteckich, a jedynie źródła archiwalne.

Pół roku później, 24 IV 1889 r. ks. dziekan Bartoszewski ponownie zwrócił się pisemnie do ks. Ślósarza z wezwaniem do zastępstwa wykładowcy Starego Testamentu o. prof. Klemensa Sarnickiego OSBM (1832-1909)23 ${ }^{23}$ udającego się na Kongres Katolicki w Wiedniu. Także tym razem adiunkt winien się porozumieć z kierownikiem katedry celem ustalenia szczegółów ${ }^{24}$. Niestety, brak dokładnych źródeł nie pozwala ustalić w tej mierze żadnych detali. Tego samego roku dotyczy relacja ks. Ślósarza o zastępstwie wykładowcy historii Kościoła, ks. prof. Józefa Delkiewicza (1822-1912) $)^{25}$, choć nie znajduje ona potwierdzenia w innych źródłach ${ }^{26}$.

Wspomniane już wcześniej kłopoty zdrowotne ks. prof. Watzki nie ustąpiły, co spowodowało konieczność dalszej pomocy ze strony adiunkta. Mianowicie pod koniec roku akad. 1888/89 profesor nie był w stanie przeprowadzić końcowych egzaminów, wskutek czego obowiązki te zlecono ks. Ślósarzowi. Tak więc w dniach 23-26 VII 1889 r. egzaminował on z zakresu Nowego Testamentu kilkudziesięciu studentów obrządku łacińskiego i greckokatolickiego ${ }^{27}$.

Według niepotwierdzonej źródłowo - poza relacją ks. Ślósarza - wzmianki w jednym z pism do Rady Wydziału Teologicznego, zastępował on przez jeden semestr roku akad. 1889/90 wykładowcę teologii pastoralnej, ks. prof. Ludwika Klossa (1845-1902) ${ }^{28}$, przebywającego okresowo w Jerozolimie ${ }^{29}$. Jeszcze jedno, tym razem oficjalnie poświadczone źródłowo zastępstwo miało miejsce w I se-

${ }^{22}$ DALO, f. 26, op. 13, nr 186, Teczka personalna ks. Jana Ślósarza, J. Bartoszewski, [Kopia pisma dziekana Wydziału Teologicznego do ks. J. Ślósarza], Lwów 29 XII 1888 r.

${ }^{23}$ H.E. WyCZAwsKI, Sarnicki Klemens, w: Stownik polskich teologów katolickich, t. IV, red. H.E. Wyczawski, Warszawa 1983, s. 22-23 (błędy i braki); Wydział Teologiczny Uniwersytetu Jana Kazimierza we Lwowie 1918-1933, s. 22.

${ }^{24}$ DALO, f. 26, op. 13, nr 186, Teczka personalna ks. Jana Ślósarza, J. Bartoszewski, [Kopia pisma do ks. J. Ślósarza], Lwów 24 IV 1889 r.

25 J. HŁystiuk, T. Leszczak, Delkewycz Josyf, w: Lwiwśkyj nacionalnyj uniwersytet, t. I, s. 427; Wydziat Teologiczny Uniwersytetu Jana Kazimierza we Lwowie 1918-1933, s. 20.

${ }^{26}$ DALO, f. 26, op. 13, nr 186, Teczka personalna ks. Jana Ślósarza, J. Ślósarz, [Podanie do Rady Wydziału Teologicznego Uniwersytetu Lwowskiego], Lwów 13 XII 1895 r.

${ }^{27}$ DALO, f. 26, op. 13, nr 186, Teczka personalna ks. Jana Ślósarza, J. Delkiewicz, Wezwanie, Lwów 17 VII $1889 \mathrm{r}$.

28 J. WolcZaŃsKi, Kloss Ludwik, w: Encyklopedia Katolicka, t. IX, Lublin 2002, kol. 157-158; Wydziat Teologiczny Uniwersytetu Jana Kazimierza we Lwowie 1918-1933, s. 29.

${ }^{29}$ DALO, f. 26, op. 13, nr 186, Teczka personalna ks. Jana Ślósarza, J. Ślósarz, [Pismo do Rady Wydziału Teologicznego Uniwersytetu Lwowskiego], Lwów 8 VI 1900 r. 
mestrze roku akad. 1890/91. Po przejściu w 1890 r. na emeryturę kierownika Katedry Historii Kościoła, ks. prof. Józefa Delkiewicza, zastępstwo wykładów powierzono w I semestrze roku akad. 1890/91 ks. dr. Janowi Ślósarzowi ${ }^{30}$, choć drukowane katalogi uniwersyteckie za zarejestrowały tego faktu ${ }^{31}$. Suplent przeprowadził nadto na koniec semestru egzamin „z nader pomyślnym skutkiem”, co potwierdzili profesorowie fakultetu ${ }^{32}$. Bliższe szczegóły na temat podręczników, z których korzystał, metod dydaktycznych oraz egzekwowanych wymagań wobec słuchaczy są nieznane.

Warto tu dodać, iż w tym samym czasie, w latach 1888-1892, duchowny pełnił funkcję prefekta lwowskiego Seminarium Duchownego ob. łac., a następnie w latach 1892-1894 nauczyciela religii w V Gimnazjum, zaś w latach 1894-1905 katechety w Wyższej Szkole Realnej we Lwowie. Obowiązki te dały mu szansę zdobycia doświadczenia pedagogicznego i umiejętności nawiązywania kontaktów międzyludzkich, co wyeksponował w staraniach o stały angaż na Uniwersytecie Lwowskim ${ }^{33}$.

Okazja ku temu nadarzyła się niebawem, kiedy to po śmierci 16 IX 1895 r. wykładowcy historii Kościoła, ks. prof. Eustachego Skrochowskiego (1834-1895) ${ }^{34}$, pojawiła się nadzieja na awans ks. Ślósarza w strukturach uniwersyteckich ${ }^{35}$. Korzystając z tej szansy, skierował on 13 XII 1895 r. podanie do Rady Wydziału Teologicznego z prośbą o nominację na wakującą katedrę. Do swego pisma dołączył m.in. opinię profesorów tegoż fakultetu, którym był już dobrze znany. Grono wykładowców stwierdzało: ,[...] iż czuje się spowodowanym nie tylko pod względem wiedzy teologicznej i działalności nauczycielskiej, ale także pod względem uprzejmości w pożyciu koleżeńskim [kandydata] jak najlepiej zalecić" ${ }^{36}$. Petent, rekomendując swoje walory intelektualne, zapewniał adresatów pisma o znajomo-

30 W. HaHn, Kronika Uniwersytetu Lwowskiego, t. 2: (1898/9 - 1909/10), Lwów 1912, s. 302.

${ }^{31}$ C.K. Uniwersytet imienia cesarza Franciszka I we Lwowie. Sktad Uniwersytetu i program wykładów w półroczu zimowym 1890/91, Lwów 1890, s. 24.

${ }^{32}$ DALO, f. 26, op. 13, nr 186, Teczka personalna ks. Jana Ślósarza, J. Ślósarz, [Podanie do Rady Wydziału Teologicznego Uniwersytetu Lwowskiego], Lwów 13 XII 1895 r.

${ }^{33}$ DALO, f. 26, op. 13, nr 186, Teczka personalna ks. Jana Ślósarza, J. Ślósarz, [Podanie do Rady Wydziału Teologicznego Uniwersytetu Lwowskiego], Lwów 13 XII 1895 r.; DALO, f. 26, op. 13, nr 186, Teczka personalna ks. Jana Ślósarza, J. Ślósarz, [Curriculum vitae], Lwów 27 X 1901 r.; DALO, f. 26, op. 13, nr 186, Teczka personalna ks. Jana Ślósarza, J. Ślósarz,, [Ankieta służbowa], bmr.

${ }^{34}$ B. MicewsKi, Skrochowski Eustachy, w: Stownik polskich teologów katolickich, t. IV, s. 98100; Wydziat Teologiczny Uniwersytetu Jana Kazimierza we Lwowie 1918-1933, s. 20.

${ }^{35}$ L. Finkel, M. Chlamtacz, Kronika Uniwersytetu Lwowskiego, t. 1: (1894/95 - 1897/98), Lwów 1899, s. 30; Wydział Teologiczny Uniwersytetu Jana Kazimierza we Lwowie 1918-1933, s. 20

${ }^{36}$ DALO, f. 26, op. 13, nr 186, Teczka personalna ks. Jana Ślósarza, J. Ślósarz, [Podanie do Rady Wydziału Teologicznego Uniwersytetu Lwowskiego], Lwów 13 XII 1895 r. 
ści przedmiotu nie tylko w sensie prowadzenia wykładów i egzaminowania studentów, ale także orientacji w źródłach historycznych, czego miała dowodzić świeżo opublikowana rozprawa jego autorstwa De investitura dissertatio (Lwów 1895). Nota bene prawdopodobnie publikacja ta była przerobioną wersją wiedeńskiego doktoratu z roku 1885, negatywnie ocenioną przez jednego z członków fakultetu teologicznego ${ }^{37}$. W dalszych wywodach petycji autor powoływał się na swoją wieloletnią praktykę dydaktyczną zarówno w charakterze adiunkta uniwersyteckiego, jak i katechety szkół średnich; w ramach obowiązków nauczycielskich zajmował się także prezentacją zagadnień z dziedziny historii Kościoła. Pogłębieniu wiedzy historycznej służyła mu podróż naukowa do Rzymu i innych miast włoskich w roku 1891, dzięki czemu zapoznał się z dziejami tych miejsc i bogatymi zabytkami architektury. W cytowanym podaniu ks. Ślósarz przytoczył nadto swoje doświadczenie pedagogiczne zarówno na niwie katechetycznej, jak i wychowawcy alumnów archidiecezji lwowskiej, co powinno ułatwić mu pełnienie obowiązków wykładowcy uniwersyteckiego. Powołał się w końcu na swój wkład w prace stałej komisji do spraw opracowania planów nauczania i aprobaty książek szkolnych, co wzbogaciło jego wiedzę o funkcjonowaniu struktury szkoły i procesów nauczania $^{38}$. Do cytowanego podania dołączonych zostało 12 załączników w formie aneksów potwierdzających kompetencje petenta w rzeczonej sprawie.

Niestety, ani autopromocja ks. Ślósarza, ani kurtuazyjne zresztą referencje jego pseudoprotektorów nie przekonały członków Rady Wydziału Teologicznego odnośnie do powierzenia mu kierownictwa Katedry Historii Kościoła na Uniwersytecie Lwowskim. Wprawdzie jednostka ta nie należała do szczególnie prestiżowych w katalogu pozostałych katedr, spośród których za renomowane uchodziły choćby: Katedra Nowego Testamentu, Katedra Starego Testamentu, Katedra Teologii Dogmatycznej, Katedra Teologii Moralnej czy wreszcie Katedra Prawa Kanonicznego z tytułu przydatności wykładanych dyscyplin w życiu przyszłych kapłanów, to mimo tego nie zamierzano angażować osoby bez żadnego dorobku naukowego z dziedziny dziejów Kościoła, choć zaznajomionej z metodami dydaktycznymi. Bądź co bądź pozycja profesora uniwersytetu cieszyła się niebywałym szacunkiem społecznym, a naukowe środowisko lwowskie na przełomie $\mathrm{XIX/XX}$ stulecia miało już ugruntowaną renomę. Stosunkowo słaby w relacji do pozostałych wydziałów Uniwersytetu Lwowskiego fakultet teologiczny pod względem osiągnięć naukowo-badawczych, bo nastawiony na praktyczny wymiar

${ }^{37}$ DALO, f. 26, op. 5, nr 220, Teczka personalna ks. Alojzego Jougana, J. Bilczewski, [Kopia pisma do Prezydium Namiestnictwa we Lwowie], Lwów 24 IX 1902 r., s. 6.

${ }^{38}$ DALO, f. 26, op. 13, nr 186, Teczka personalna ks. Jana Ślósarza, J. Ślósarz, [Podanie do Rady Wydziału Teologicznego Uniwersytetu Lwowskiego], Lwów 13 XII 1895 r. 
formacji studentów, nie mógł sobie pozwolić na mianowanie kandydata wręcz przypadkowego, skoro o nominację zabiegały osoby cieszące się wyrobioną sławą naukową. Tak było i w tym wypadku. Petycja ks. Ślósarza pozostała więc bez echa, a po upływie dziewięciu miesięcy, 21 IX 1896 r. nominację na kierownika Katedry Historii Kościoła uzyskał ks. prof. Jan Fijałek (1864-1936) ${ }^{39}$, wybitny już wówczas uczony, a w niedalekiej przyszłości jeden z najznakomitszych polskich historyków Kościoła ${ }^{40}$.

Dotkliwa porażka w zabiegach o katedrę uniwersytecką nie położyła bynajmniej kresu marzeniom ks. Ślósarza o karierze naukowej. Postanowił zrealizować je metodą zdobycia ugruntowanej pozycji w świecie nauki, a następnie sięgnąć po upragniony cel. Tym razem zamierzał poświęcić się studiom w zakresie teologii pastoralnej. Pięć lat po nieudanych poprzednich staraniach, 8 VI 1900 r. wniósł podanie do Rady Wydziału Teologicznego Uniwersytetu Lwowskiego o otwarcie postępowania habilitacyjnego na podstawie drukowanej rozprawy $O$ cenzurach kościelnych i ekskomunikach $w$ szczególny sposób papieżowi zastrzeżonych (Lwów 1900). Przytaczając wszystkie etapy dotychczasowej pracy zawodowej, wyraźnie wyeksponował elementy związane z procesem dydaktyczno-naukowym zarówno na Uniwersytecie Lwowskim (adiunktura, wykłady i egzaminy w zastępstwie nieobecnych profesorów), jak i staż pedagogiczny (nauczyciel w szkołach średnich i prowadzący praktyczne ćwiczenia pastoralne z alumnami Seminarium Duchownego $)^{41}$.

Na recenzentów rozprawy habilitacyjnej wyznaczono spośród grona miejscowego fakultetu teologicznego dwóch profesorów: kierownika Katedry Teologii Pastoralnej ks. Jana Bartoszewskiego i kierownika Katedry Teologii Moralnej ks. Stanisława Narajewskiego. Obie recenzje można uznać za nader lakoniczne, pomijając ich objętość; każda z nich zajmowała zaledwie jedną stronicę papieru formatu in folio. Pierwszy z recenzentów uznał rozprawę za spełniającą wymogi stawiane tego typu pracom do uzyskania habilitacji. Pisał: „Jest to bowiem rozprawa mająca wartość naukową, oparta na dziełach naukowych ten przedmiot gruntownie traktujących, a wyczerpująca obrany temat zupełnie. Autor wyraża się krótko, jędrnie, a mimo to jasno, przedstawia rzecz logicznie i w systematycznym porządku. Największą zaś zaletą tej rozprawy jest to, że autor daje w niej praktyczne wskazówki mogące posłużyć osobliwie dla początkujących spowiedników, jako przewodnik

39 L. Finkel, M. Chlamtacz, Kronika Uniwersytetu Lwowskiego, t. 1, s. 117; P. Palka, Fijałek Jan, w: Encyklopedia Katolicka, t. V, Lublin 1989, kol. 178-180.

${ }^{40}$ DALO, f. 26, op. 13, nr 186, Teczka personalna ks. Jana Ślósarza, J. Ślósarz, [Pismo do Rady Wydziału Teologicznego Uniwersytetu Lwowskiego], Lwów 8 VI 1900 r.

${ }^{41}$ Tamże. 
w sprawowaniu Sakramentu pokuty [...]"42. Ponadto przyznał tej pracy walory zarówno metodologiczne, jak i praktyczne, podkreślając przy tym poprawny i piękny język narracji.

Druga opinia analizowała formalną strukturę dysertacji, zwracając uwagę na dysproporcję pomiędzy częścią pierwszą - teoretyczną a drugą - praktyczną. Recenzent wytykał autorowi zbyt powierzchowne opracowanie pierwszej z nich. Podkreślił wszakże i zalety pracy: poprawny warsztat metodologiczny, cytowanie w wersji oryginalnej dokumentów papieskich i kongregacji Stolicy Apostolskiej, zestawienie najnowszych rozporządzeń watykańskich odnośnie do omawianego tematu ${ }^{43}$.

Obie zatem recenzje miały pozytywny wydźwięk, jakkolwiek nie wspominały o dopuszczeniu kandydata do dalszych etapów przewodu habilitacyjnego. Widocznie postulat ten uznano za oczywisty. Podczas posiedzenia Rady Wydziału Teologicznego 29 X 1900 r. oceniono rozprawę ks. Ślósarza „[...] za wystarczającą do uzyskania venia docendi" ${ }^{44}$. W tej sytuacji ówczesny dziekan Wydziału Teologicznego, ks. prof. Józef Komarnicki pismem z 3 XI 1900 r. zawiadomił habilitanta o decyzji grona profesorskiego, a jednocześnie zaprosił go na kolokwium habilitacyjne dnia 6 listopada t.r. Równocześnie wezwał kandydata do przedłożenia Radzie Wydziału Teologicznego trzech tematów, z których ta wybierze jeden jako przedmiot wykładu habilitacyjnego ${ }^{45}$.

Zapowiedziane kolokwium odbyło się zgodnie z planem. Uczestniczyło w nim ośmiu profesorów: ks. Józef Komarnicki - dziekan, o. Klemens Sarnicki OSBM, ks. Jan Bartoszewski, ks. Józef Bilczewski, ks. Jan Fijałek, ks. Błażej Jaszowski, ks. Stanisław Narajewski i ks. Jan Żukowski. Dziewiąty z członków komisji ks. Ludwik Kloss - usprawiedliwił swą nieobecność z powodu urlopu zdrowotnego. W kolokwium czynnie uczestniczyli obaj recenzenci oraz dwaj członkowie komisji: ks. prof. Jaszowski i o. prof. Sarnicki, zadając kandydatowi szereg pytań. Tak więc ks. prof. Bartoszewski postawił mu 15 kwestii do rozwiązania, dotyczących rezerwatów papieskich stosowanych w spowiedzi, jak też szczegółowych zagadnień związanych z praktyką spowiedzi. Natomiast ks. prof. Narajewski zlecił mu dwa problemy do zreferowania również z dziedziny sakramentu pokuty. Na pytania obu recenzentów habilitant udzielił zadowalających odpowiedzi. Podobnie rzecz się

${ }^{42}$ DALO, f. 26, op. 13, nr 186, Teczka personalna ks. Jana Ślósarza, J. Bartoszewski, [Recenzja rozprawy habilitacyjnej ks. dr. J. Ślósarza], Lwów 4 IX 1900 r.

${ }^{43}$ DALO, f. 26, op. 13, nr 186, Teczka personalna ks. Jana Ślósarza, S. Narajewski, [Recenzja rozprawy habilitacyjnej ks. dr. J. Ślósarza], Lwów 25 X 1900 r.

${ }^{44}$ DALO, f. 26, op. 13, nr 186, Teczka personalna ks. Jana Ślósarza, J. Komarnicki, [Kopia pisma dziekana fakultetu teologicznego do ks. J. Ślósarza], Lwów 3 XI 1900 r.

${ }^{45}$ Tamże. 
miała z rezultatem pytań i odpowiedzi pozostałych egzaminatorów. Końcowy werdykt komisji brzmiał następująco: ,[...] kandydat należycie opanował przedmiot do którego się habilituje, zna jego literaturę, biegle włada językiem polskim, więc posiada kwalifikację potrzebną dla docenta teologii pasterskiej" "46. Podjęto zatem decyzję o dopuszczeniu kandydata do wykładu, wybierając temat: „Jak ma kaznodzieja poruszyć wolę słuchacza"? Termin wykładu wyznaczono na dzień 15 XI 1900 r. ${ }^{47}$

Tegoż dnia, o godz. 11,45 ponownie zebrała się w kancelarii Dziekanatu Wydziału Teologicznego komisja habilitacyjna w składzie jak poprzednio, z wyjątkiem chorego ks. prof. Klossa i zajętego inną pracą ks. prof. Bilczewskiego. Po przejściu do sali wykładowej, habilitant wygłosił z pamięci w obecności zebranych wykład habilitacyjny. W protokole z posiedzenia zanotowano końcową ocenę występu ks. Ślósarza: „[...] kandydat posiada głos donośny i wyraźny, akcentuje odpowiednio i cały wykład był z godnością i namaszczeniem wygłoszony" ${ }^{48}$. Reasumując finał postępowania habilitacyjnego, członkowie komisji jednomyślnie postanowili udzielić kandydatowi veniam docendi ${ }^{49}$.

Dnia 5 XII 1900 r. z dziekanatu Wydziału Teologicznego Uniwersytetu Lwowskiego skierowano więc komplet dokumentów do Ministerstwa Wyznań i Oświaty w Wiedniu z prośbą o zatwierdzenie habilitacji ks. Jana Ślósarza w zakresie teologii pastoralnej ${ }^{50}$. Pozytywna decyzja w tej kwestii nosiła datę 6 V 1901 r., co tym samym oznaczało dla zainteresowanego włączenie go do grona prywatnych docentów ${ }^{51}$. W ślad za tym, ks. dziekan prof. Józef Komarnicki poinformował ks. Ślósarza o pomyślnym zakończeniu postępowania habilitacyjnego ${ }^{52}$.

46 Tamże.

47 Tamże.

48 Tamże. Charakterystyczna jest kwintesencja oceny, koncentrująca się nie na meritum, lecz na walorach wokalnych habilitanta. Taką zresztą praktykę stosowano zarówno na Wydziale Uniwersytetu Teologicznego Uniwersytetu Jagiellońskiego, jak i Uniwersytetu Lwowskiego. Widocznie zakładano, że merytoryczne atuty wykładów kandydatów do habilitacji są bezdyskusyjne, a jedyną przeszkodę w uzyskaniu aprobaty może stanowić defekt natury akustycznej.

49 Tamże.

50 DALO, f. 26, op. 13, nr 186, Teczka personalna ks. Jana Ślósarza, J. Komarnicki, [Kopia pisma dziekana Wydziału Teologicznego do Ministerstwa Wyznań i Oświaty w Wiedniu], Lemberg 5 X 1900 r.

51 Tytuł naukowy docenta prywatnego przyznawano w krajach niemieckojęzycznych - do których należała wówczas Galicja - osobom po uzyskaniu habilitacji. Nie byli oni wszakże etatowymi pracownikami uczelni. DALO, f. 26, op. 13, nr 186, Teczka personalna ks. Jana Ślósarza, [Pismo Ministerstwa Wyznań i Oświaty w Wiedniu do Dziekanatu Wydziału Teologicznego Uniwersytetu Lwowskiego], Wien $6 \mathrm{~V} 1901 \mathrm{r}$.

52 DALO, f. 26, op. 13, nr 186, Teczka personalna ks. Jana Ślósarza, J. Komarnicki, [Kopia pisma dziekana Wydziału Teologicznego do ks. doc. dr. hab. Jana Ślósarza], Lwów 21 V 1900 r. 
Uzyskanie stopnia doktora habilitowanego nie otwierało bynajmniej automatycznie drzwi do pracy dydaktyczno-naukowej. Wiele zależało od konkretnych potrzeb wynikających z konieczności uzupełnienia składu grona pedagogicznego, uszczuplonego wskutek wypadków losowych, bądź obsady nowo kreowanych etatów. Ta ostatnia z wymienionych okoliczności na przełomie XIX/XX wieku raczej nie wchodziła $\mathrm{w}$ rachubę na galicyjskich fakultetach teologicznych, bowiem nie rozbudowywano planu studiów; taka perspektywa pojawiła się dopiero w Polsce Odrodzonej po roku $1918^{53}$. W tej sytuacji pozostawały dla docentów tylko godziny zlecone. Taki też los spotkał ks. Ślósarza. Mianowicie przyznano mu w II semestrze roku akad. 1901/02 zaledwie jedną godzinę wykładu „O udzielaniu świętego Sakramentu pokuty", w roku następnym wykładał ten sam przedmiot w analogicznym wymiarze przez dwa semestry ${ }^{54}$. Łatwo zrozumieć frustrację młodego stażem, choć zaawansowanego wiekiem 51-letniego decenta, który nawet po zdobyciu habilitacji nie miał większych szans na objęcie Katedry Teologii Pastoralnej; tą bowiem aż do 13 II 1902 r. kierował ks. prof. Ludwik Kloss. Zanim zmarł 13 marca tegoż roku, pojawiły się dodatkowe przeszkody ${ }^{55}$.

Mianowicie we lwowskim środowisku naukowym wyłonił się poważny konkurent do objęcia tejże katedry w osobie ks. doc. Alojzego Jougana, kapłana archidiecezji lwowskiej. Nie miał on wprawdzie ukończonych studiów w ośrodkach uniwersyteckich poza Galicją, gdyż doktorat uzyskał w roku 1888 we Lwowie, ale podobnie jak ks. Ślósarz habilitował się tamże 25 VI 1901 r. również w zakresie teologii pastoralnej ${ }^{56}$. Dzielił ich więc okres zaledwie miesiąca od uzyskania docentury, jednak decydującą przewagę miał ks. Jougan. Od daty uzyskania doktoratu do habilitacji mógł się wylegitymować znaczącym dorobkiem pisarskim: bibliografia jego prac drukowanych liczyła ponad 80 artykułów i rozpraw, przeszło 220 recenzji oraz 14 samoistnych dzieł i publikacji; spośród tych pozycji 84 dotyczyły w ścisłym znaczeniu teologii pastoralnej ${ }^{57}$. Nic więc dziwnego, że 7 sa-

53 J. WolczańsKi, Wydział Teologiczny, passim; S. PIech, Wydział Teologiczny, passim; Wydziat Teologiczny Uniwersytetu Jana Kazimierza 1918-1933, s. 37-80.

${ }^{54}$ Zob. tabela $1 \mathrm{w}$ niniejszym artykule. C.K. Uniwersytet imienia cesarza Franciszka I we Lwowie. Skład Uniwersytetu i program wykładów w pótroczu letnim 1901/02 - 1902/03, Lwów 19011902, passim.

${ }^{55}$ W. Hahn, Kronika, t. 2, s. 284.

56 J. WolCZAŃsKi, Wydział Teologiczny, s. 264.

57 Niekompletna - jak się okazuje - bibliografia prac drukowanych ks. Jougana we współczesnym opracowaniu liczy za ten okres zaledwie 34 pozycje! DALO, f. 26, op. 5, nr 220, Teczka personalna ks. Alojzego Jougana, A. Jougan, [Pismo do Rady Wydziału Teologicznego Uniwersytetu Lwowskiego], Lwów 12 XII 1900 r.; DALO, f. 26, op. 5, nr 220, Teczka personalna ks. Alojzego Jougana, A. Jougan, Wykaz działalności i pracy pisarskiej ogłoszonej drukiem, Lwów 12 XIII 1900 r.; 
modzielnych publikacji o niewielkim ciężarze gatunkowym oraz jeden przekład katechizmu z j. niemieckiego w dorobku ks. Ślósarza nie były w stanie żadną miarą rywalizować z imponującą spuścizną jego kolegi ${ }^{58}$.

Pomiędzy obu kandydatami do objęcia wakującej Katedry Teologii Pastoralnej toczyły się swoiste zaoczne zmagania. Sytuację skomplikował dodatkowo fakt pojawienia się jeszcze trzeciego konkurenta w osobie ks. doc. Adama Gerstmanna $(1873-1940)^{59}$, który również uzyskał habilitację w zakresie teologii pastoralnej na Wydziale Teologicznym Uniwersytetu Lwowskiego nawet rok wcześniej przed obu wspomnianymi wyżej duchownymi, bo $9 \mathrm{~V} 1900$ r. ${ }^{60}$ Podczas posiedzenia Rady Wydziału Teologicznego dnia 26 VI 1902 r., usiłowano położyć kres zaistniałemu impasowi, wysuwając dwie równorzędne kandydatury: ówczesnego katechety gimnazjalnego ks. doc. Alojzego Jougana ,[... ] ze względu na jego prace naukowe [...]"61 i ks. doc. Jana Ślósarza, bez podania szczegółowej motywacji. Rozmyślnie pominięto osobę ks. doc. Adama Gerstmanna, ,[...] a to ze względu na wiek jego młody i brak doświadczenia potrzebnego dla profesora teologii pasterskiej, jako przedmiotu praktycznego w duszpasterstwie" ${ }^{2}$. Wniosek ten uchwalono jednomyślnie, kierując stosowne pismo do wiedeńskiego Ministerstwa Wyznań i Oświaty. Warto w tym miejscu zaznaczyć, iż we wszystkich zachowanych dokumentach dotyczących kwestii obsady owej katedry pojawiał się wątek wykazania się przez kandydatów praktyką duszpasterską. Niezwykle mocno wybrzmiał w tej kwestii głos ks. Jougana, zobligowanego trybem postępowania habilitacyjnego do podda-

K. Pį̨TKA, Jougan Władysław Alojzy, w: Stownik polskich teologów katolickich, t. V, red. L. Grzebień, Warszawa 1983, s. 616-619.

${ }^{58}$ Były to: Geschichtlicher Abriss des Seminars der Lemberger Erzdiöcese ritus latini, w: H. Zsснокке, Die theologische Studien und Anstalten der katholischen Kirche in Österreich, Wien-Leipzig 1894, s. 994-1000; De investitura dissertatio (Leopoli 1895); Katechizm religii katolickiej dla młodzieży szkót średnich (Lwów 1897, 1899²); Egzorta przy rozpoczęciu II pótrocza. (Dla szkót średnich), „Dwutygodnik Katechetyczny i Duszpasterski” 1(1897), s. 37-41; O. Julian Ślósarz, „Gazeta Kościelna" 7(1898), nr 23, s. 150-152; O cenzurach kościelnych i ekskomunikach w szczególny sposób papieżowi zastrzeżonych (Lwów 1900); Władza kluczów w Sakramencie Pokuty (Lwów 1902) oraz przekład z j. niemieckiego: Mały katechizm religii rzymsko-katolickiej (Lwów1898). J. WoŁCZAŃSKI, Ślósarz Jan, s. 42-43.

59 J. WolcZaŃski, Wydziat Teologiczny, s. 257; W. Hahn, Kronika, t. II, s. 301-302; P. HeMPeREK, Gerstmann Adam, w: Encyklopedia Katolicka, t. V, Lublin 1989, kol. 1022.

${ }^{60}$ J. WolCZaŃski, Wydział Teologiczny, s. 257.

${ }^{61}$ DALO, f. 26, op. 5, nr 220, Teczka personalna ks. Alojzego Jougana, Protokół posiedzenia Kolegium Profesorów Wydziału Teologicznego c.k. Uniwersytetu we Lwowie z dnia 26 czerwca 1902 r. w sprawie obsadzenia Katedry teologii pastoralnej z polskim językiem wykładowym, Lwów 26 VI $1902 \mathrm{r}$.

62 Tamże. 
nia się egzaminowi ustnemu przed komisją profesorską. Kandydat powiadomiony o tym warunku wystosował do niezidentyfikowanego członka tegoż gremium pismo kwestionujące zasadność owego wymogu w stosunku do swojej osoby. Powoływał się przy tym na precedensy stosowane na innych fakultetach lwowskiej uczelni, a przede wszystkim na swoje długoletnie zaangażowanie w pracę duszpasterską o wielorakim charakterze. Jakby dla kontrastu przytoczył przy tym przypadek ks. Jana Ślósarza, który habilitował się z teologii pastoralnej, nigdy wcześniej nie zajmując się tą dziedziną, podczas gdy on już w latach 1884/85 - 1885/86 jeszcze przed uzyskaniem stopnia doktora teologii pełnił obowiązki adiunkta na Wydziale Teologicznym Uniwersytetu Lwowskiego, wykładając teologię pastoralną i egzaminując studentów w zastępstwie ks. prof. Ludwika Klossa. Ponadto jako prefekt Seminarium Duchownego w latach 1883-1888 wykładał alumnom przez dwa lata homiletykę, a kilkadziesiąt publikacji z dziedziny teologii pastoralnej ogłoszonych drukiem stanowiło najlepszą rekomendację jego kompetencji merytorycznych ${ }^{63}$. Argumenty te wyłożone ze swadą, a zarazem potwierdzające zasadność zastrzeżeń odnośnie do warunków postępowania habilitacyjnego przekonały komisję egzaminacyjną, bowiem na posiedzeniu dnia 5 VI 1901 r. zwolniono ks. Jougana z egzaminu ustnego $0^{64}$.

Decydującym wszakże elementem w rozstrzygnięciu obsady Katedry Teologii Pastoralnej w sytuacji braku jednoznacznej decyzji Rady Wydziału Teologicznego był głos metropolity lwowskiego abp. Józefa Bilczewskiego, byłego profesora tegoż fakultetu, rektora lwowskiej uczelni, a przy tym doskonale zorientowanego w kompetencjach kandydatów z grona duchowieństwa archidiecezji. W odpowiedzi na pismo Prezydium Namiestnictwa we Lwowie z 12 IX 1902 r. żądające decydującego rozstrzygnięcia wątpliwości, hierarcha przedstawił obszerny elaborat analizujący naukowe i praktyczne predyspozycje kandydatów. Już w tym miejscu należy dodać, że opinia ta ostatecznie zaważyła na położenie kresu wakatu katedry. Dla ścisłości warto nadmienić, iż autorem elaboratu nie był wszakże lwowski metropolita, lecz niezidentyfikowany duchowny, być może z grona profesorskiego, świetnie zorientowany w predyspozycjach obu kandydatów, a hierarcha składając swój autograf zaaprobował w pełni tok przygotowanej pisemnie argumentacji.

${ }^{63}$ DALO, f. 26, op. 5, nr 220, Teczka personalna ks. Alojzego Jougana, List ks. Alojzego Jougana do NN, Lwów 26 V 1901 r.; DALO, f. 26, op. 5, nr 220, A. Jougan, Curriculum vitae, Lemberg 10 VI $1902 \mathrm{r}$.

${ }^{64}$ DALO, f. 26, op. 5, nr 220, Teczka personalna ks. Alojzego Jougana, J. Komarnicki, [Kopia pisma dziekana Wydziału Teologicznego do ks. A. Jougana], Lwów 11 VI 1901 r.; DALO, f. 26, op. 5, nr 220, Teczka personalna ks. Alojzego Jougana, Protokół posiedzenia Kolegium Profesorów Wydziału Teologicznego c.k. Uniwersytetu we Lwowie z dnia 5 czerwca 1901 r. w sprawie obsadzenia Katedry teologii pastoralnej z polskim językiem wykładowym, Lwów 25 VI 1901 r. 
$\mathrm{Na}$ wstępie opracowania autor podkreślił niezwykłą rangę wykładów teologii pastoralnej w procesie uwieńczenia intelektualnej formacji studentów. Doceniając ten fakt, akcentował konieczność desygnowania na wykładowcę najbardziej przygotowanego do tej roli kandydata, a takiego spoza Lwowa nie umiał wskazać. W dłuższym wywodzie podkreślał wymóg erudycyjnego przygotowania kandydata, gdyż wykłady winny bazować na wiedzy z dziedziny dogmatyki, etyki, prawa kanonicznego i cywilnego, psychologii, pedagogiki, socjologii, a nadto odwoływać się do osobistej praktyki duszpasterskiej. Wskazywał nadto na osobowościowe walory przyszłego profesora: praktyczną zaradność i dynamizm, jak również znajomość realiów lokalnego Kościoła archidiecezji lwowskiej obrządku łacińskiego. Metropolita przyznawał zatem rację Radzie Wydziału Teologicznego, która opowiedziała się za kandydatami miejscowymi najlepiej zorientowanymi w specyfice złożonych stosunków kościelno-religijnych i społeczno-politycznych Galicji Wschodniej. Odwołując się do decyzji grona profesorskiego z 26 VI 1902 r., akceptował tymczasową rezygnację z osoby najmłodszego z kandydatów, ks. Adama Gerstmanna, wprawdzie najzdolniejszego, ale bez dostatecznego doświadczenia pastoralnego. Pozostali dwaj: ks. Alojzy Jougan i ks. Jan Ślósarz, mieli wiele cech wspólnych - praktykę duszpasterską na parafii, staż na etatach wychowawców alumnów i katechetów gimnazjalnych, nieprzeciętne przymioty charakteru i ducha. Ale obu różniło sporo innych elementów. I tak ks. Jougana charakteryzowała niezwykła ruchliwość organizatorska, społeczna i naukowa, dłuższy o 6 lat od ks. Ślósarza staż duszpasterski, udział w akcji prezentacji wykładów otwartych na aktualne tematy, zaangażowanie w misji kaznodziejskiej, uczestnictwo w stowarzyszeniach i organizacjach katolickich. Owa wielokierunkowa aktywność dobrze świadczyła o permanentnym rozwoju duchownego ${ }^{65}$.

O wiele gorzej na tym tle wypadła charakterystyka ks. Jana Ślósarza. Lwowski metropolita podkreślił, iż zaczął on później w stosunku do ks. Jougana edukację szkolną. Już jako kapłan przez ponad cztery lata studiował w Wiedniu ${ }^{66}$, tylko sporadycznie udzielając się na innych polach niż naukowe. W środowisku lwowskim „[...] rzadko kiedy w roku szkolnym wychylał się poza dom i szkołę, a wakacje spędzał regularnie w rodzinnym swym miejscu, odciętej od świata Węglówce. Wprawdzie wielkie położył zasługi około odkupienia przez miasto kościoła Klarysek i jego restauracji, czyni też chwalebne i gorliwe zabiegi w celu pozyskania kościoła św. Wojciecha i budynków do niego należących na rzecz bursy gimnazjalnej, ale starania te nie rozszerzyły jego widnokręgów, nie przysporzyły mu doświad-

${ }^{65}$ DALO, f. 26, op. 5, nr 220, Teczka personalna ks. Alojzego Jougana, J. Bilczewski, [Kopia pisma do Prezydium Namiestnictwa we Lwowie], Lwów 24 IX 1902 r., s. 1-5.

${ }^{66} \mathrm{~W}$ rzeczywistości przebywał na studiach 5 lat. 
czenia, więc nie stanowią kwalifikacji do objęcia profesury uniwersyteckiej"67. Autor memoriału wskazał też na dysproporcję pomiędzy drukowanym dorobkiem obu kandydatów na korzyść ks. Jougana. Pisał: „Ks. Ślósarz ogłosił drukiem trzy rzeczy: «O inwestyturze», rozprawę słabą, ignorującą nowsze w tym przedmiocie badania, a nienależącą do zakresu teologii pastoralnej; «O cenzurach kościelnych» (Lwów 1900, str. 102 w 8-ce), kompilację, na której literatura polska nic nie zyskała, bo gruntowniej tę materię opracował ks. Dr Opieliński profesor w Gnieźnie; wreszcie rozprawę «O władzy kluczów w Kościele», rzecz więcej dogmatyczną niż pasterską" ${ }^{68}$. Publikacje te nie wskazywały bynajmniej na zainteresowanie autora dziedziną teologii pastoralnej, inaczej niż prace ks. Jougana. Ten ostatni górował nad swoim konkurentem również w dziedzinie formy wypowiedzi, co nie jest obojętne w sytuacji pracy ze studentami nad poprawnością wyrażania myśli. Ponadto: „Ks. Ślośarz ma umysł raczej recepcyjny niż produktywny; to co przeczytał zachowa wiernie w pamięci i powtórzy, lecz nie przetworzy $[\ldots]^{\prime 69}$. Autor opinii przewidywał, iż odpowiednio ukierunkowany będzie on mógł skutecznie funkcjonować na każdym odpowiedzialnym stanowisku, podczas gdy ks. Jougan od najwcześniejszych lat zmierzał do osiągnięcia uczciwymi metodami katedry uniwersyteckiej. Reasumując swoje rozważania, metropolita jednoznacznie opowiedział się za desygnowaniem przez Ministerstwo Wyznań i Oświaty osoby ks. Jougana na stanowisko profesora zwyczajnego Katedry Teologii Pastoralnej z polskim językiem wykładowym ${ }^{70}$.

Ostatecznie postulat ten doczekał się realizacji na mocy cesarskiego dekretu z 7 IV 1903 r., przyznającego ks. doc. Jouganowi nominację na profesora nadzwyczajnego teologii pastoralnej z polskim językiem wykładowym na Wydziale Teologicznym Uniwersytetu Lwowskiego ${ }^{71}$. Dwa lata później, 20 VIII 1905 r. uzyskał on awans na profesora zwyczajnego tegoż przedmiotu ${ }^{72}$.

Tytułem dopowiedzenia warto dodać, iż Katedra Teologii Pastoralnej nie miała jednak szczęścia do kierowników. Zaledwie dwa lata później, wskutek nieznanego bliżej konfliktu z abp. Józefem Bilczewskim, ks. prof. Jougan został przezeń zmuszony do rezygnacji ze stanowiska w wieku 52 lat, a więc w pełni rozwoju

${ }^{67}$ DALO, f. 26, op. 5, nr 220, Teczka personalna ks. Alojzego Jougana, J. Bilczewski, [Kopia pisma do Prezydium Namiestnictwa we Lwowie], Lwów 24 IX 1902 r., s. 4-5.

${ }_{68}$ Tamże, s. 5-6.

69 Tamże, s. 6.

${ }^{70}$ Tamże, s. 7.

${ }^{71}$ DALO, f. 26, op. 5, nr 220, Teczka personalna ks. Alojzego Jougana, L. Ćwikliński, [Dekret szefa Ministerstwa Wyznań i Oświaty o nominacji ks. doc. A. Jougana na prof. nadzwyczajnego], Wien 18 IV 1903 r.

72 J. WolCZaŃski, Wydziat Teologiczny, s. 264. 
sił twórczych. Dekret emerytalny otrzymał 14 IV 1907 r. $^{73}$ Wówczas na widowni ponownie pojawił się ks. doc. Adam Gerstmann, który z polecenia Ministerstwa Wyznań i Oświaty objął zastępstwo wykładów teologii pastoralnej ${ }^{74}$. Jeszcze tego samego roku, 19 XII 1907 r., został mianowany profesorem nadzwyczajnym, a 6 VIII 1910 r. profesorem zwyczajnym tegoż przedmiotu. Katedrą Teologii Pastoralnej kierował do roku akad. 1919/20 włącznie ${ }^{75}$, po czym w II Rzeczypospolitej rozpoczęły się nowe dzieje katedry niezwiązane już z niniejszym tematem.

Tak więc kandydatura ks. doc. Jana Ślósarza na etat profesora uniwersyteckiego ostatecznie przepadła. On sam zapewne nie uważał tej funkcji za warunek sine qua non swojej egzystencji, preferując raczej działalność katechetyczną, kościelną i biurokratyczną w administracji lokalnego Kościoła niż trud uczonego teologa oraz pisarza. Jeszcze przez kilka lat jego nazwisko pojawiało się w katalogach wykładowców i planie wykładów Wydziału Teologicznego, a nawet w roku akad. 1902/03 był delegatem docentów do kolegium profesorskiego. Poza jednogodzinnym wykładem w II semestrze roku akad. 1901/02 i I-II semestrze roku akad. 1902/03, nie prowadził - oprócz sporadycznych zastępstw nieobecnych profesorów - żadnych innych zajęć uniwersyteckich, co zresztą rejestruje niżej zamieszczona tabela 1. Ponadto w roku akad. 1902/03 pełnił obowiązki delegata docentów do kolegium profesorów fakultetu teologicznego ${ }^{76}$. W katalogach składu osobowego i wykładów Uniwersytetu Lwowskiego aż do swej śmierci w roku 1917 figurował jako docent prywatny w kategorii: „Członkowie ciała nauczycielskiego nie należący do grona profesorów", ale nie był w jakikolwiek sposób czynnie zaangażowany $\mathrm{w}$ życie uczelni ${ }^{77}$. Po poniesionej porażce $\mathrm{w}$ staraniach o angaż profesorski skierował się w stronę tzw. kariery kościelnej, uzyskując 30 XII 1904 r. nominację na kanonika gremialnego Kapituły Metropolitalnej ob. łac. we Lwowie ${ }^{78}$. Na tym stanowisku spędził 13 ostatnich lat swego życia.

73 DALO, f. 26, op. 5, nr 220, [Kopia pisma Namiestnictwa we Lwowie do Kurii Metropolitalnej ob. łac. tamże], Lwów 16 V 1907 r.

${ }^{74}$ Tamże.

75 J. Wolczański, Wydziat Teologiczny, s. 257.

${ }^{76}$ C.K. Uniwersytet imienia cesarza Franciszka I we Lwowie. Sktad Uniwersytetu i program wykładów w pótroczu zimowym 1902/03, Lwów 1902, s. 7; C.K. Uniwersytet imienia cesarza Franciszka I we Lwowie. Skład Uniwersytetu i program wykładów w pótroczu letnim 1902/03, Lwów 1903, s. 7.

${ }_{77}$ C.K. Uniwersytet imienia cesarza Franciszka I we Lwowie. Sktad Uniwersytetu i program wykładów 1902/03-1917/18, Lwów 1902-1917, passim.

${ }^{78}$ Archiwum Archidiecezji Lwowskiej ob. łac. w Krakowie, Akta Konsystorskie 1901, J. Ślósarz, Podanie do Kurii Metropolitalnej ob. łac. we Lwowie, Lwów 27 X 1901 r.; DALO, f. 26, op. 13, nr 186, Teczka personalna ks. Jana Ślósarza, Tabela służbowa ks. Jana Ślósarza, bmr. 
Tabela 1

Działalność dydaktyczna ks. Jana Ślósarza na Uniwersytecie Lwowskim w latach 1889/90 - 1902/03

\begin{tabular}{|c|c|c|l|c|}
\hline L.p. & Rok akademicki & Semestr & \multicolumn{1}{|c|}{ Tytuł wykładu } & $\begin{array}{c}\text { Liczba } \\
\text { godzin }\end{array}$ \\
\hline 1 & $1888 / 89$ & $?$ & $\begin{array}{l}\text { Nowy Testament } \\
\text { (zastępstwo ks. prof. Józefa Watzki) }\end{array}$ & $?$ \\
\cline { 3 - 5 } & & $?$ & $\begin{array}{l}\text { Stary Testament } \\
\text { (zastępstwo o. prof. Klemensa Sarnickiego OSMB) }\end{array}$ & $?$ \\
\cline { 3 - 5 } & $?$ & $\begin{array}{l}\text { Historia ecclesiastica } \\
\text { (zastępstwo ks. prof. Józefa Delkiewicza) }\end{array}$ & $?$ \\
\hline 2 & $1889 / 90$ & $?$ & $\begin{array}{l}\text { Teologia pastoralna } \\
\text { (zastępstwo ks. prof. Ludwika Klossa) }\end{array}$ & 7 \\
\hline 3 & $1890 / 91$ & I & $\begin{array}{l}\text { Historia ecclesiastica } \\
\text { (zastępstwo ks. prof. Józefa Delkiewicza) }\end{array}$ & 9 \\
\hline 4 & $1901 / 02$ & II & O udzielaniu św[iętego] Sakramentu pokuty & 1 \\
\hline 5 & $1902 / 03$ & I- II & O udzielaniu św[iętego] Sakramentu pokuty & 1 \\
\hline
\end{tabular}

Źródło: C.K. Uniwersytet imienia cesarza Franciszka I we Lwowie. Skład Uniwersytetu i program wykładów 1888/89 - 1902/03, Lwów 1887-1902, passim.

Wydaje się, że ambicje ks. Jana Ślósarza w zabiegach o wejście do elitarnego panteonu profesorów Uniwersytetu Lwowskiego przewyższały jego uzdolnienia i merytoryczne kompetencje. Nie można odmówić mu solidnego wykształcenia, choć bez wyraźnego ukierunkowania na określoną dziedzinę nauki, pracowitości, rzetelności oraz uczciwości w realizacji zamierzeń, ale zbrakło mu pasji i fascynacji badawczej, a wreszcie przysłowiowego szczęścia. Pomimo fiaska podjętych zabiegów, jego życie wolno uznać za spełnione, bowiem realizował się w innych obszarach pracy społeczno-religijnej, odnosząc tam spektakularne sukcesy.

\section{BIBLIOGRAFIA}

\section{Źródła rękopiśmienne}

Derżawnyj Archiw Lwiwśkoji Obłasti u Lwowi [DALO] Zespół: Uniwersytet Jana Kazimierza we Lwowie

f. 26, op. 13, nr 186, Teczka personalna ks. Jana Ślósarza

- J. Ślósarz, [Curriculum vitae], Lwów 27 X 1901 r.

- J. Ślósarz, [Podanie do Rady Wydziału Teologicznego Uniwersytetu Lwowskiego], Lwów 3 XI $1886 \mathrm{r}$.

- [M. Paliwoda, Nota dziekana Wydziału Teologicznego Uniwersytetu Lwowskiego w sprawie obsady stanowiska adiunkta], Lwów 6 XI 1886 r. 
- [M. Paliwoda, Kopia pisma do Konsystorza Metropolitalnego ob. łac.], Lwów 23 XI $1886 \mathrm{r}$.

- S. Morawski, Odezwa, Lwów 3 I 1887 r.

- S. Sembratowicz, Nota, Leopoli 28 I 1887 r.

- [M. Paliwoda, Kopia pisma do Namiestnictwa we Lwowie], Lwów 23 XI 1886 r.

- [Kopia pisma Namiestnictwa do Głównej Kasy Krajowej we Lwowie], Lwów 29 XII $1886 \mathrm{r}$.

- [Kopia pisma dziekana Wydziału Teologicznego Uniwersytetu Lwowskiego do ks. J. Ślósarza], Lwów 24 I 1887 r.

- [Nota w sprawie petycji ks. J. Ślósarza o przedłużenie kadencji adiunkta], Lwów 5 X $1888 \mathrm{r}$.

- [Kopia pisma dziekana Wydziału Teologicznego Uniwersytetu Lwowskiego do ks. J. Ślósarza], Lwów 26 XI 1888 r.

- [Kopia pisma dziekana Wydziału Teologicznego Uniwersytetu Lwowskiego do Namiestnictwa we Lwowie], Lwów 26 XI $1888 \mathrm{r}$.

- [Kopia pisma Namiestnictwa do Głównej Kasy Krajowej we Lwowie], Lwów 30 XI $1888 \mathrm{r}$.

- [Curriculum vitae], Lwów 27 X 1901 r.

- [Kopia pisma dziekana Wydziału Teologicznego do ks. J. Ślósarza], Lwów 29 XII 1888 r.

- J. Bartoszewski, [Kopia pisma do ks. J. Ślósarza], Lwów 24 IV 1889 r.

- J. Ślósarz, [Podanie do Rady Wydziału Teologicznego Uniwersytetu Lwowskiego], Lwów 13 XII $1895 \mathrm{r}$.

- J. Delkiewicz, Wezwanie, Lwów 17 VII 1889 r.

- J. Ślósarz, [Pismo do Rady Wydziału Teologicznego Uniwersytetu Lwowskiego], Lwów 8 VI $1900 \mathrm{r}$.

- J. Ślósarz, [Podanie do Rady Wydziału Teologicznego Uniwersytetu Lwowskiego], Lwów 13 XII $1895 \mathrm{r}$.

- J. Ślósarz, [Podanie do Rady Wydziału Teologicznego Uniwersytetu Lwowskiego], Lwów 13 XII $1895 \mathrm{r}$.

- J. Ślósarz, [Ankieta służbowa], bmr.

- J. Ślósarz, [Podanie do Rady Wydziału Teologicznego Uniwersytetu Lwowskiego], Lwów 13 XII $1895 \mathrm{r}$.

- J. Ślósarz, [Pismo do Rady Wydziału Teologicznego Uniwersytetu Lwowskiego], Lwów 8 VI $1900 \mathrm{r}$.

- J. Bartoszewski, [Recenzja rozprawy habilitacyjnej ks. dr. J. Ślósarza], Lwów 4 IX 1900 r.

- S. Narajewski, [Recenzja rozprawy habilitacyjnej ks. dr. J. Ślósarza], Lwów 25 X 1900 r.

- J. Komarnicki, [Kopia pisma dziekana fakultetu teologicznego do ks. J. Ślósarza], Lwów 3 XI $1900 \mathrm{r}$.

- J. Komarnicki, [Kopia pisma dziekana Wydziału Teologicznego do Ministerstwa Wyznań i Oświaty w Wiedniu], Lemberg 5 X $1900 \mathrm{r}$.

- [Pismo Ministerstwa Wyznań i Oświaty w Wiedniu do Dziekanatu Wydziału Teologicznego Uniwersytetu Lwowskiego], Wien 6 V $1901 \mathrm{r}$. 
- J. Komarnicki, [Kopia pisma dziekana Wydziału Teologicznego do ks. doc. dr. hab. Jana Ślósarza], Lwów 21 V 1900 r.

- Tabela służbowa ks. Jana Ślósarza, bmr.

f. 26, op. 5, nr 220, Teczka personalna ks. Alojzego Jougana

- J. Bilczewski, [Kopia pisma do Prezydium Namiestnictwa we Lwowie], Lwów 24 IX 1902 r., s. 6.

- A. Jougan, [Pismo do Rady Wydziału Teologicznego Uniwersytetu Lwowskiego], Lwów 12 XII $1900 \mathrm{r}$.

- A. Jougan, Wykaz działalności i pracy pisarskiej ogłoszonej drukiem, Lwów 12 XIII $1900 \mathrm{r}$.

- Protokół posiedzenia Kolegium Profesorów Wydziału Teologicznego c.k. Uniwersytetu we Lwowie z dnia 26 czerwca 1902 r. w sprawie obsadzenia Katedry teologii pastoralnej z polskim językiem wykładowym, Lwów 26 VI 1902 r.

- List ks. Alojzego Jougana do NN, Lwów 26 V 1901 r.

- A. Jougan, Curriculum vitae, Lemberg 10 VI 1902 r.

- J. Komarnicki, [Kopia pisma dziekana Wydziału Teologicznego do ks. A. Jougana], Lwów 11 VI $1901 \mathrm{r}$.

- Protokół posiedzenia Kolegium Profesorów Wydziału Teologicznego c.k. Uniwersytetu we Lwowie z dnia 5 czerwca 1901 r. w sprawie obsadzenia Katedry teologii pastoralnej z polskim językiem wykładowym, Lwów 25 VI $1901 \mathrm{r}$.

- J. Bilczewski, [Kopia pisma do Prezydium Namiestnictwa we Lwowie], Lwów 24 IX 1902 r., s. 1-5.

- L. Ćwikliński, [Dekret szefa Ministerstwa Wyznań i Oświaty o nominacji ks. doc. A. Jougana na prof. nadzwyczajnego], Wien 18 IV 1903 r.

- [Kopia pisma Namiestnictwa we Lwowie do Kurii Metropolitalnej ob. łac. tamże], Lwów 16 V 1907 r.

Archiwum Archidiecezji Lwowskiej ob. łac. w Krakowie

Zespół: Akta Konsystorskie 1901 r.

bsygn., J. Ślósarz, Podanie do Kurii Metropolitalnej ob. łac. we Lwowie, Lwów 27 X 1901 r.

\section{Źródla drukowane}

C.K. Uniwersytet imienia cesarza Franciszka I we Lwowie. Skład Uniwersytetu i program wykładów 1886/87 - 1917/18, Lwów 1886-1917.

Finkel L., Chlamtacz M., Kronika Uniwersytetu Lwowskiego, t. 1: (1894/95 - 1897/98), Lwów 1899.

HaHn H., Kronika Uniwersytetu Lwowskiego, t. 2: (1898/9 - 1909/10), Lwów 1912.

ŚLÓSARZ J., Geschichtlicher Abriss des Seminars der Lemberger Erzdiöcese ritus latini, w: H. ZschoкKe, Die theologische Studien und Anstalten der katholischen Kirche in Österreich, Wien-Leipzig 1894, s. 994-1000.

ŚlósARZ J., De investitura dissertatio, Leopoli 1895. 
ŚLÓSARZ J., Katechizm religii katolickiej dla młodzieży szkół średnich, Lwów 1897; 1899².

ŚLósARZ J., Egzorta przy rozpoczęciu II półrocza. (Dla szkół średnich), „Dwutygodnik Katechetyczny i Duszpasterski" 1(1897), s. 37-41.

ŚlósarZ J., O. Julian Ślósarz, „Gazeta Kościelna” 7(1898), nr 23, s. 150-152.

ŚLósARz J., O cenzurach kościelnych i ekskomunikach w szczególny sposób papieżowi zastrzeżonych, Lwów 1900.

Ślósarz J., Władza kluczów w Sakramencie Pokuty, Lwów 1902.

Mały katechizm religii rzymsko-katolickiej, tłum. z j. niem. J. Ślósarz, Lwów 1898.

\section{Opracowania}

FrankL K.H., Das Höhere Priesterbildungsinstitut zu St. Augustin in Wien („Frintaneum”), w: Das „Frintaneum in Wien” und seine Mitglieder aus den Kirchenprovinzen Wien, Salzburg und Görz (1816-1918). Ein biographisches Lexikon, hgg. K.H. Frankl, P.G. Tropper, Ljubjana-Wien: Hermagoras 2006, s. 21-38.

HempereK P., Gerstmann Adam, w: Encyklopedia Katolicka, t. V, Lublin 1989, kol. 1022.

HŁystiuk J., LeszczaK T., Delkewycz Josyf, w: Lwiwśkyj nacionalnyj uniwersytet imeni Iwana Franka. Encyklopedia, t. I, red. zbior., Lwiw 2011, s. 427.

Kanior M., Wydział Teologiczny w dziejach Uniwersytetu Krakowskiego (1780-1880), Kraków: Wydawnictwo Naukowe 1998.

Kochowski W., Historia Seminarium Duchownego diecezji przemyskiej obrządku łacińskiego 1687-1895, oprac. J. Wołczański, Lwów-Kraków: Wydawnictwo Bł. Jakuba Strzemię Archidiecezji Lwowskiej Obrządku Łacińskiego 2011.

Micewski B., Skrochowski Eustachy, w: Słownik polskich teologów katolickich, t. IV, red. H.E. Wyczawski, Warszawa: ATK 1983, s. 98-100.

OwsINŚKYJ J., Watcka (Watzka) Józef, w: Lwiwśkyj nacionalnyj uniwersytet imeni Iwana Franka. Encyklopedia, t. I, red. zbior., Lwiw 2011, s. 271.

PAŁKA P., Fijałek Jan, w: Encyklopedia Katolicka, t. V, Lublin: TN KUL 1989, kol. 178-180.

Piech S., Wychować dla Kościoła i państwa. Formacja elity duchowieństwa galicyjskiego w Wiedniu 1775-1918, Kraków: Wydawnictwo UNUM 2012.

PIECH S., Wydział Teologiczny Uniwersytetu Jagiellońskiego w latach 1880-1939, Kraków 1995.

Piętka K., Jougan Władysław Alojzy, w: Słownik polskich teologów katolickich, t. V, red.

L. Grzebien, Warszawa: ATK 1983, s. 616-619.

WoŁCZAŃski J., Ślósarz Jan, w: Polski Słownik Biograficzny, t. 51, red. zbior., WarszawaKraków: IH PAN 2016, s. 42-43.

WolCZAŃsKi J., Wydział Teologiczny Uniwersytetu Jana Kazimierza we Lwowie 19181939, Kraków: Wydawnictwo Bł. Jakuba Strzemię Archidiecezji Lwowskiej Obrządku Łacińskiego 2002.

WolCZAŃSKI J., Wydział Teologiczny, w: Academia militans. Uniwersytet Jana Kazimierza we Lwowie, red. A. Redzik, Kraków: Wydawnictwo Wysoki Zamek, IPN 2017, s. 291-383.

WolCZAŃSKI J., Jaszowski Błażej, w: Encyklopedia Katolicka, t. VII, Lublin: TN KUL 1997, kol. 1115. 
WoŁcZAŃSKi J., Kloss Ludwik, w: Encyklopedia Katolicka, t. IX, Lublin: TN KUL 2002, kol. 157-158.

WyCZawski H.E., Sarnicki Klemens, w: Słownik polskich teologów katolickich, t. IV, red. H.E. Wyczawski, Warszawa: ATK 1983, s. 22-23.

Wydział Teologiczny Uniwersytetu Jana Kazimierza we Lwowie 1918-1933, red. zbior., Lwów 1934.

\section{DZIAŁALNOŚĆ DYDAKTYCZNO-NAUKOWA KS. JANA ŚLÓSARZA NA WYDZIALE TEOLOGICZNYM UNIWERSYTETU LWOWSKIEGO W LATACH 1886-1903}

\section{Streszczenie}

Niniejsze opracowanie prezentuje uniwersytecką karierę duchownego archidiecezji lwowskiej obrządku łacińskiego, ks. doc. dr. hab. Jana Ślósarza (1850-1917). Po uzyskaniu doktoratu z teologii w roku 1855 na Wydziale Teologicznym Uniwersytetu Wiedeńskiego, powrócił do Lwowa, pełniąc m.in. obowiązki katechety szkół średnich. Nie porzucił wszakże planów dalszych awansów naukowych. W latach 1886/87-1890/91 został zatrudniony na Wydziale Teologicznym Uniwersytetu Lwowskiego w charakterze adiunkta. W zastępstwie nieobecnych profesorów wykładał dorywczo kilka dyscyplin. I tak zimą 1888 r. zastępował wykładowcę Nowego Testamentu ks. prof. Józefa Watzkę. Wiosną 1889 r. zlecono mu wykłady Starego Testamentu w miejsce o. prof. Klemensa Sarnickiego OSBM. W 1890 r. zastąpił ks. prof. Józefa Delkiewicza na Katedrze Historii Kościoła. Równocześnie do tych zajęć, w latach 1888-1892 duchowny pełnił funkcję prefekta lwowskiego Seminarium Duchownego ob. łac., a następnie w latach 1892-1894 nauczyciela religii w V Gimnazjum, zaś w latach 1894-1905 katechety w Wyższej Szkole Realnej we Lwowie. Docelowym wszakże marzeniem ks. Ślósarza była profesura uniwersytecka. Zabiegał o nią już w roku 1895, kiedy wakowała Katedra Historii Kościoła, ale bezskutecznie. Ponownie podjął starania w roku 1900, otwierając przewód habilitacyjny w zakresie teologii pastoralnej na Uniwersytecie Lwowskim. Habilitację uzyskał bez większych trudności, a jej zatwierdzenie przez Ministerstwo Wyznań i Oświaty nastąpiło w 1891 r. Katedra Teologii Pastoralnej była wszakże zajęta, choć po śmierci jej kierownika w 1902 r. pojawiła się realna nadzieja. Otrzymał wprawdzie zastępstwo wakującej katedry, ale bez nominacji na jej kierownictwo. Pomimo podjęcia starań o tę schedę, ks. Ślósarz bezapelacyjnie przegrał konkurencję z dysponującym tak praktycznym doświadczeniem pastoralnym, jak i znaczącym dorobkiem pisarskim i organizacyjnym ks. doc. Alojzym Jouganem. Na otarcie łez powierzono mu w latach 1901-1903 wykłady zlecone w minimalnym wymiarze godzin na temat Sakramentu Pokuty. Zrażony niepowodzeniami ks. Ślósarz skierował się ku innej sferze działalności; mianowicie w roku 1904 r. otrzymał nominację na kanonika gremialnego Kapituły Metropolitalnej we Lwowie, piastując tę godność przez ostatnie 13 lat swego życia.

Słowa kluczowe: abp Józef Bilczewski; ks. Jan Ślósarz; ks. Ludwik Kloss; ks. Józef Delkiewicz; ks. Alojzy Jougan; Frintaneum; Uniwersytet Lwowski; Wydział Teologiczny; Katedra Teologii Pastoralnej; Kapituła Metropolitalna we Lwowie 


\title{
TEACHING AND SCIENTIFIC ACTIVITIES OF FR. JAN ŚLÓSARZ AT THE THEOLOGICAL FACULTY OF THE UNIVERSITY OF LVIV IN THE YEARS 1886-1903
}

\begin{abstract}
Sum mary
This article presents the university career of a clergyman of the Archdiocese of Lviv of the Latin rite, Dr. habil. Jan Ślósarz (1850-1917). After obtaining his doctoral degree in theology in 1855 at the Faculty of Theology of the University of Vienna, he returned to Lviv, where he was employed as a secondary school catechist. However, he did not abandon his plans for further scientific career. In the years 1886/87-1890/91 he was employed at the Faculty of Theology of the University of Lviv as an assistant professor. He gave lectures, on and off, on several subjects in place of absent professors. For instance, in the winter of 1888, he replaced the New Testament lecturer, Fr. Józef Watzke. In the spring of 1889 he was commissioned to give lectures on the Old Testament in place of Fr. Klemens Sarnicki OSBM. In 1890 he replaced Fr. Józef Delkiewicz at the Department of Church History. Simultaneously, in 1888-1892 the clergyman served as a prefect of the Lviv Seminary of the Latin rite, and then in 1892-1894 as a teacher of religion in the Fifth Grammar School, and in 1894-1905 as a catechist in the High Real School in Lviv. However, the ultimate dream of Fr. Ślósarz was a university professorship. He sought it already in 1895, when the Department of Church History was vacant, but to no avail. He tried again in 1900, opening his habilitation procedure in the field of pastoral theology at the University of Lviv. He obtained his habilitation degree without any major difficulties, and it was approved by the Ministry of Religions and Education in 1891. The Department of Pastoral Theology was, however, not vacant. But after the death of its head in 1902, a real opportunity presented itself. Fr. Ślósarz was made an interim acting head of the department, though he did not receive a formal nomination. In spite of his efforts, Fr. Ślósarz eventually lost the competition for the new head of the department to Fr. Alojzy Jougan, who had practical pastoral experience plus considerable writing and organisational experience. As a consolation he was entrusted with commissioned lectures in 1901-1903 on the Sacrament of Penance. Discouraged by his failures, Fr. Ślósarz turned to another sphere of his activity - in 1904 he was nominated a canon of the Metropolitan Chapter in Lviv, holding this position for the last 13 years of his life.
\end{abstract}

Keywords: Archbishop Józef Bilczewski; Fr. Jan Ślósarz; Fr. Ludwik Kloss; Fr. Józef Delkiewicz; Fr. Alojzy Jougan; Frintaneum; University of Lviv; Faculty of Theology; Department of Pastoral Theology; Lviv Metropolitan Chapter 